\title{
Climate Change and Occupational Health and Safety in a Temperate Climate: Potential Impacts and Research Priorities in Quebec, Canada
}

\author{
Ariane ADAM-POUPART ${ }^{1 *}$, France LABRÈCHE ${ }^{1,2}$, Audrey SMARGIASSI $^{3}$ \\ Patrice DUGUAY ${ }^{2}$, Marc-Antoine BUSQUE ${ }^{2}$, Charles GAGNÉ ${ }^{2}$, \\ Hannu RINTAMÄKI ${ }^{4}$, Tord KJELLSTROM ${ }^{5,6}$ and Joseph ZAYED ${ }^{1,2}$
}

\footnotetext{
${ }^{1}$ Department of Environmental and Occupational Health, Faculty of Medicine, University of Montreal, Canada

${ }^{2}$ Institut de recherche Robert-Sauvé en santé et en sécurité du travail (IRSST), Canada

${ }^{3}$ Chaire sur la pollution de l'air, les changements climatiques et la santé, Faculté de Médecine, University of Montreal, Canada

${ }^{4}$ Finnish Institute of Occupational Health, Physical Work Capacity Team, Finland

${ }^{5}$ Center for Global Health Research, Umeå University, Sweden

${ }^{6}$ National Center for Epidemiology and Population Health, Australian National University, Australia
}

Received July 14, 2012 and accepted November 9, 2012

\begin{abstract}
The potential impacts of climate change (CC) on Occupational Health and Safety (OHS) have been studied a little in tropical countries, while they received no attention in northern industrialized countries with a temperate climate. This work aimed to establish an overview of the potential links between CC and OHS in those countries and to determine research priorities for Quebec, Canada. A narrative review of the scientific literature (2005-2010) was presented to a working group of international and national experts and stakeholders during a workshop held in 2010. The working group was invited to identify knowledge gaps, and a modified Delphi method helped prioritize research avenues. This process highlighted five categories of hazards that are likely to impact OHS in northern industrialized countries: heat waves/increased temperatures, air pollutants, UV radiation, extreme weather events, vector-borne/zoonotic diseases. These hazards will affect working activities related to natural resources (i.e. agriculture, fishing and forestry) and may influence the socioeconomic context (built environment and green industries), thus indirectly modifying OHS. From this consensus approach, three categories of research were identified: 1) Knowledge acquisition on hazards, target populations and methods of adaptation; 2) Surveillance of diseases/ accidents/occupational hazards; and 3) Development of new occupational adaptation strategies.
\end{abstract}

Key words: Climate change, Occupational health and safety, Research priorities, Northern industrialized country, Delphi method

*To whom correspondence should be addressed. Email: ariane.apoupart@gmail.com

(C)2013 National Institute of Occupational Safety and Health

\section{Introduction}

Over the last twenty years, most scientists have agreed regarding the rapid progression of climate change (CC). According to the conclusions of the fourth Assessment Report of the Intergovernmental Panel on Climate Change 
(IPCC), climate changes and global warming are unequivocal $^{1,2)}$. The IPCC predicts that the average warming of the earth's surface, associated with increased concentrations of $\mathrm{CO}_{2}$ in the atmosphere, will lead to major changes in ecosystem structures and ecological interactions, with negative impacts on biodiversity and ecosystems' goods and services such as water and food supplies ${ }^{2)}$. Consequently, important environmental changes are expected all over the world: 1) variability of temperature, rainfall, humidity and winds, 2) alteration of intensity and geographic distribution of extreme climatic events, 3) significant rise of water levels in coastal areas, 4) alteration of wildlife distribution, 5) increased atmospheric concentrations of pollutants and 6) deterioration of natural habitats and of the built environment ${ }^{2-6)}$.

The impacts of climate conditions on human health are multiple and have been extensively studied in the general population ${ }^{1}$. But to date, the working population has received little attention and no research has analyzed climate change impacts specifically in northern countries, despite evidences of impacts on the labor market ${ }^{7)}$. For instance, new climate conditions may favor hydroelectricity and forestry production and increase agricultural crops such as maize and soy in northern countries. On the other hand, climate change may also affect negatively workers' health and safety because of thermal constraints exacerbation and modification of natural resources that are the basis of the economy ${ }^{6}$

A most useful preliminary framework for identifying how climate change could affect occupational health and safety (OHS) worldwide was published in $2009^{8)}$. In addition to general research and practice considerations, this framework identified seven categories of hazards (increased ambient temperature, air pollution, UV radiation, extreme weather events, vector-borne and zoonotic diseases, changes in the built environment and emerging industries) and linked some health effects and types of work to them. Among the recommendations of the authors, two were targeting further development of the framework: the assessment of the relative magnitude and frequency of climaterelated hazards on a regional basis and the development of a research and prevention agenda as well as a prioritization scheme.

In this perspective, the objectives of this work were to 1) establish an overview of the potential links between $\mathrm{CC}$ and OHS in northern industrialized countries with a temperate climate, and to 2) determine associated research priorities applicable to the Quebec (Canada) context.

\section{Methods}

A narrative review of the scientific literature was done and validated by a working group of international and national experts and Quebec's stakeholders. To determine associated research priorities, a modified Delphi method was carried out with the same working group ${ }^{9)}$.

\section{Review of the literature}

Data sources, extraction and synthesis

Research articles or reviews published in peer-reviewed scientific journals between January 2005 and December 2010 were retrieved from several bibliographic databases (Embase, Pubmed, Medline, Web of Science, Toxline, Chemical Abstracts). The following keywords were used: climate, climate change or global warming, with work or occupation. Ten articles published before 2005 and obtained by snowball literature search were also consulted.

Commentaries, editorials and opinion letters were excluded, together with papers in other languages than English or French. The resulting documents were examined and only occupational studies that mentioned negative impacts of CC were retained; exceptionally, some articles pertaining to the general population were included when the information on workers was scarce and data on the general population could be inferred to workers (e.g. air pollution and workers' health). In addition, the documents had to address CC hazards, diseases, zoonoses and health effects already found or plausible in northern industrialized countries with a temperate climate. Papers on extreme cold weather were excluded because climatic predictions suggest warmer winters in Quebec. Reports and relevant information were accessed from governmental or scientific institutions, often through their web sites, such as the IPCC, the United Nations Environment Programme (UNEP), the World Health Organization (WHO), the U.S. Environmental Protection Agency (US EPA), the Center for Disease Control and Prevention (CDC), the National Institute for Occupational Safety and Health (NIOSH) and the U.S. Army, the United Kingdom National Health Service (NHS), the Quebec consortium on climate change Ouranos, Health Canada (HC), Environment Canada (EC), and Natural Resources Canada (NRC).

Finally, exposure/hazards, potential effects on OHS and the types of industries potentially affected were extracted from the retained documents, synthesised and organized following the Schulte and Chun framework ${ }^{8)}$. 
Data verification

In order to verify the completeness of the review of literature, a summary of collected information was presented to a working group of national and international experts and some Quebec's stakeholders, during a two-day workshop held in November $2010(\mathrm{n}=19)$. Experts $(\mathrm{n}=7)$ were selected to ensure a broad expertise on CC hazards/ impacts and OHS, while stakeholders $(n=12)$ were selected in order to represent the major industrial sectors potentially affected by CC in Quebec. Therefore, the experts' group was composed of two specialists in the OHS effects of ambient temperatures and thermal constraints, two in $\mathrm{CC}$ health and environment impacts/adaptation, one in general health and emergency medicine, one in zoonoses and one in UV radiation impacts on human health. Moreover, stakeholders from agriculture, construction, forestry, mining, municipal services, transportation, fisheries, wind power and public health took part in the working group.

\section{Identification of the local research priorities}

Establishment of research topics

During the workshop, experts and stakeholders were asked to identify knowledge gaps on CC impacts identified in the literature review. Based on their expertise and interests, the literature review and the workshop discussions, the working group established a list of research topics that would address those gaps.

\section{Prioritization of research topics}

A modified Delphi approach was used to identify research priorities. The Delphi technique is based on sequential consultations in order to seek consensus on priority issues by a procedure of voting over a choice of topics. The process usually stops when consensus is reached or agreement on priorities is sufficiently advanced ${ }^{9)}$.

This list of research topics was sent by e-mail to all members of the working group $(n=19)$ and of the research team $(n=7)$. Respondents were asked to complete and comment the list of research topics established during the workshop. Returned responses were examined and a revised list of research topics was produced and passed around to the same persons. In this instance, participants were asked to rank the ten most important research topics, and to add remarks at will. Votes were summed, providing a final list of research topics.

\section{Results}

Figure 1 presents a flow chart of the studies' selection for the literature review. The initial key words search yielded 15,097 papers. Applying the inclusion/exclusion criteria previously mentioned left 219 scientific articles for review.

The information on potential negative impacts of $\mathrm{CC}$ on OHS retrieved from the literature review, with the addition of the working group comments, is summarized in Fig. 2 and references are presented in Table 1. This information is essentially organized according to the framework provided by Schulte and $\mathrm{Chun}^{8)}$, with the addition of the most concerned industries, which appeared to be the most appropriate way of presenting our findings. Three levels of impacts emerge from this information consolidation: impacts on workers, impacts on natural resources and impacts on the socio-economic context. Among the impacts on workers, five categories of direct and indirect hazards were identified: heat waves and increased temperatures, air pollutants, UV radiation, extreme weather events, vectorborne and zoonotic diseases. Impacts on natural resources are associated with changes in agriculture/breeding methods, alteration in the fishing industry and disruption of the forest ecosystem. In addition, two modifications on the socio-economic working context that could pose OHS threats were identified: deterioration of the built environment and emerging green industries.

Even in a temperate climate, the increased temperatures and the raised frequency and severity of heat waves over the coming decades is likely to increase the risk of cramps, fatigue and heatstroke, the absorption of chemicals, skin problems and possibly the risk of injuries and accidents related to a decrease in vigilance, manual dexterity and altered emotional state. Smog events are also likely to become more frequent and impact workers' health and safety by increasing the risk of cardiovascular and respiratory symptoms and diseases. Human exposure to UV radiation will also be more important, resulting in increased risks of eye and skin diseases from UV radiation, while extreme weather events are expected to be on the rise, increasing health problems and injuries. Moreover, vector-borne and zoonotic diseases may also increase and 'new' disorders, scarce or never seen in Quebec before, might also appear because of changes in geographic distribution of vectors and parasites. Impacts of CC on natural resources might affect OHS by influencing economic activities and work environments, resulting in an increase of health problems related to work insecurity in economic sectors where reduced productivity may happen. CC may also affect the effectiveness, service life and safety of infrastructures and buildings, increasing health and safety risks such as acci- 


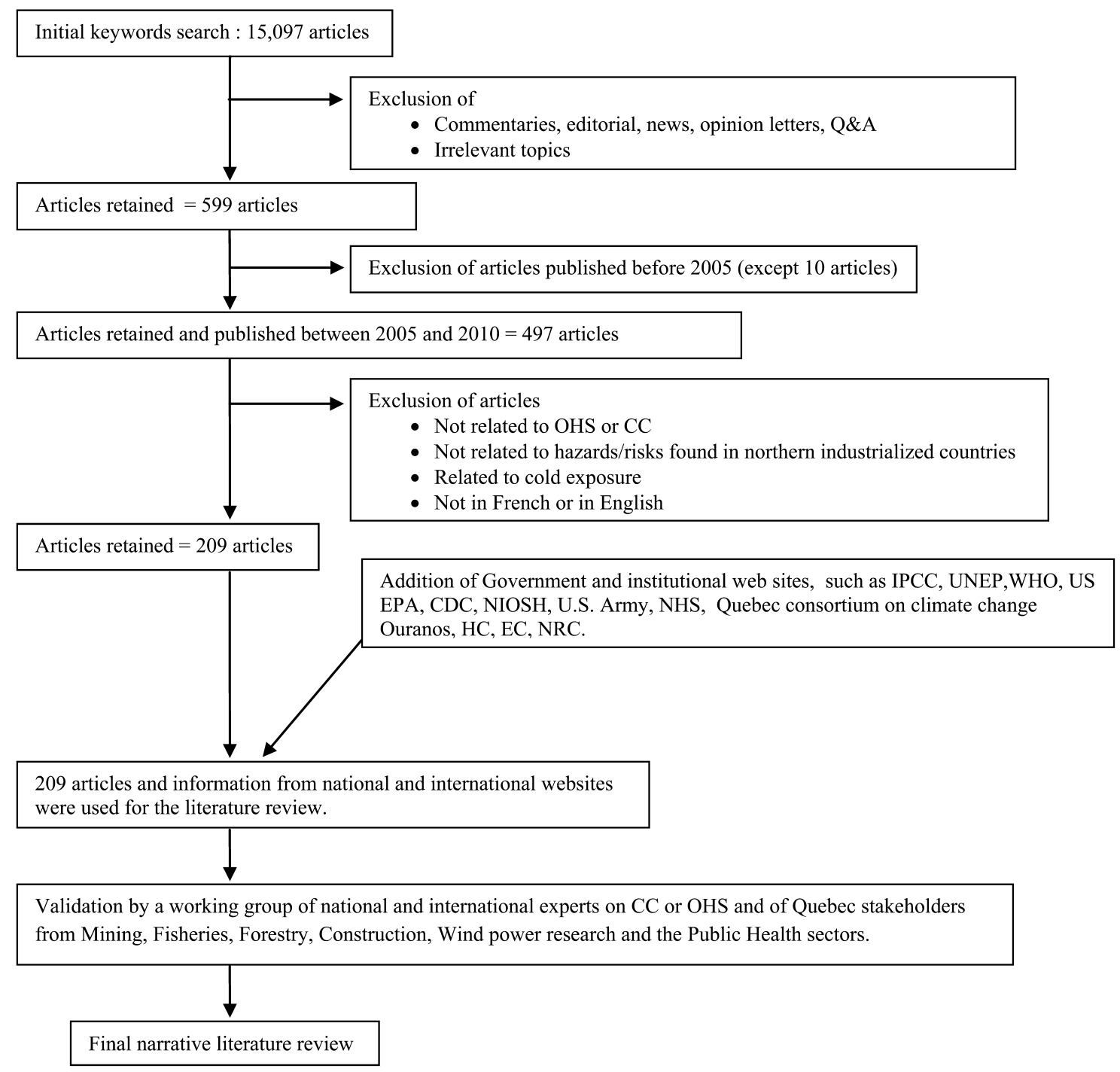

Fig. 1. Flow chart representing the studies selection for the literature review and data validation.

dents and injuries. Finally, the development of new green industries in order to mitigate the impacts of $\mathrm{CC}$ by reducing greenhouse gas emissions might also bring new OHS issues. In addition to hazards and negative OHS effects of $\mathrm{CC}$, the literature review also targeted types of industries that will potentially be affected by each category of hazard/exposure, as identified in Fig. 2 (all specific references are presented in Table 1).

Most of these industries imply outdoor activities, such as construction, agriculture, forestry, mining, fishing, municipal services and transportation. However, some indoor activities were also identified, essentially in relation to heat waves (e.g. foundries or health care) and green jobs hazards (e.g. recycling or energy industries). Moreover, numerous factors may influence the intensity of OHS effects following an exposure to CC related hazards, such as the type and location of work and the length of exposure $8,35,38,43,60,61)$ individual characteristics and physical conditions such as age, pregnancy, body weight or medication intake ${ }^{11,12,62-64)}$, the wearing of protective equipments ${ }^{65,66)}$, exposure characteristics of the hazards such as pollutant concentrations ${ }^{3)}$ and co-exposure to multiple environmental hazards ${ }^{67}$.

A list of 30 research topics was first derived from exchanges during the workshop. Twelve research topics (Table 2) were prioritized using a modified Delphi method with 17 participants replying to two rounds of consultation. Six research topics were related to knowledge acquisition on hazards, target populations and methods of adaptation in the workplace, one research topic to surveil- 


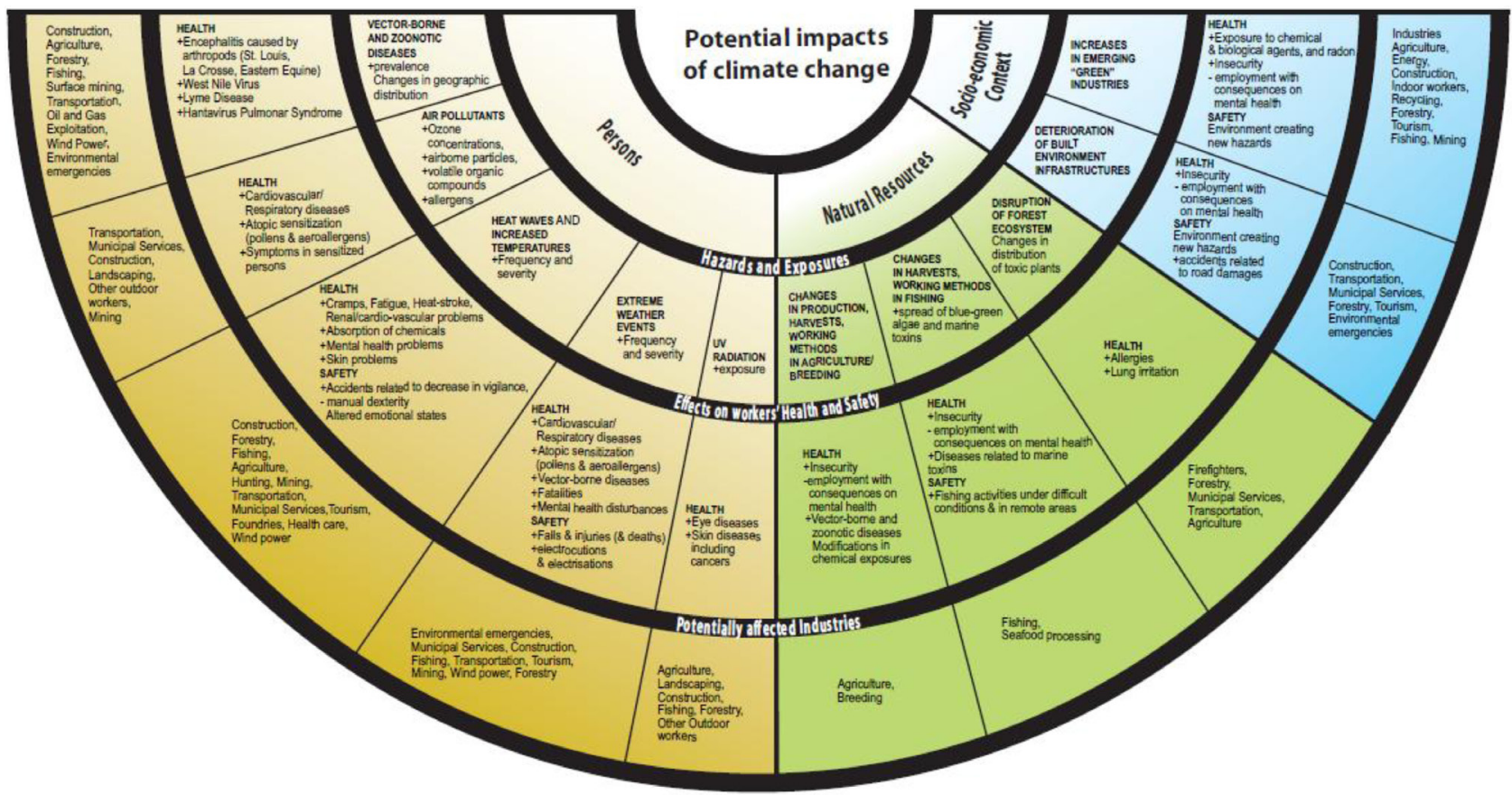

Fig. 2. Main potential impacts of $\mathrm{CC}$ on $\mathrm{OHS}$ found in northern industrialized countries.

lance of diseases, accidents and occupational hazards, and five topics to development of occupational adaptation strategies.

\section{Discussion}

The first objective of this project was to establish an overview of the negative impacts of CC on OHS in an industrialized country with a temperate climate such as Quebec (Canada). The literature review, completed by consulting a working group, identified the main exposure/hazards related to $\mathrm{CC}$, their potential effects on workers' health and safety and the type of industries potentially affected. Our research led us to conclude that the regional assessment of this issue presented few differences compared to the global framework developed by Schulte and Chun ${ }^{8)}$, and the study completed the framework by identifying a list of local industries likely to be negatively impacted by CC.

Our literature review contained the same five large hazards that could impact directly or indirectly OHS (heat waves and increased temperatures, air pollutants, UV radiation, extreme weather events, and vector-borne and zoonotic diseases). Two other impacts, which might potentially affect the socio-economic context, were also retained, as did Schulte and $\mathrm{Chun}^{8)}$ in their framework; these are the deterioration of the built environment and emerging green industries with new OHS hazards. However, our review identified impacts that could affect the work environment changes in agriculture/breeding methods, alteration in the fishing industry, and disruption of the forest ecosystem; Schulte and Chun had considered these as part of the context influencing global $\mathrm{CC}$ instead of impacts of $\mathrm{CC}^{8)}$.

The regional assessment of CC impacts emphasizes that some aspects identified by Schulte and $\mathrm{Chun}^{8)}$ were not important in the Quebec context. For example, the northern location of Quebec makes it unlikely that malaria or venomous snake bites ever become regional hazards. The input of the working group has also brought to light potential regional OHS impacts and affected industries that were not found in the published literature or identified in Schulte and Chun's framework; for example, warmer winters are associated with permafrost changes that affect surface mining infrastructures and airport runways in the North. This was added as an OHS effect in the Built Environment category (Fig. 2).

According to Adisesh et al. ${ }^{68)}$, the effects of climate change are likely to have relevance to occupational health and safety across all sectors of industry, such as emergency response, water supply, agriculture, energy, transportation, construction, etc. Our findings are in agreement with their conclusions, and suggest that $\mathrm{CC}$ in Quebec are likely to affect a large range of indoor and outdoor sectors. 
Table 1. Main references reporting evidence on climate change hazards and their effects on occupational health and safety in northern industrialized countries with a temperate climate

\begin{tabular}{|c|c|c|}
\hline Hazards & Effects on health and safety & References \\
\hline \multicolumn{3}{|l|}{ Impacts of $\mathrm{CC}$ on persons } \\
\hline \multirow{8}{*}{$\begin{array}{l}\text { Heat waves and increased tempera- } \\
\text { tures }\end{array}$} & - Cramps, Fatigue and Heatstroke & 10-13) \\
\hline & - Renal \& cardiovascular problems & 14) \\
\hline & - Increased absorption of chemicals & $15,16)$ \\
\hline & - Dehydration and decrease in cognitive performance & 17) \\
\hline & - Skin problems & $\begin{array}{l}\text { Exchanges during Montreal CC and OHS } \\
\text { workshops, Nov. 24-25, } 2010\end{array}$ \\
\hline & $\begin{array}{l}\text { - Accidents related to decrease in vigilance; decrease in } \\
\text { manual dexterity }\end{array}$ & $18,19)$ \\
\hline & - Altered emotional states & 20) \\
\hline & - Death & $13,21-23)$ \\
\hline Air pollutants & - Cardiovascular/ Respiratory symptoms and diseases & $12,24-30)$ \\
\hline (Ozone, airborne particles, volatile & - Atopic sensitization and increased allergic symptoms & $3,31)$ \\
\hline \multicolumn{3}{|l|}{ organic compound and allergens) } \\
\hline UV Radiation & - Skin diseases including cancer and eye diseases & $32-35)$ \\
\hline \multirow[t]{6}{*}{ Extreme weather events } & - Cardiovascular/ respiratory diseases & $4,12,36)$ \\
\hline & - Atopic sensitization (pollen and aeroallergens) & $3,27)$ \\
\hline & - Vector borne diseases & $4,12)$ \\
\hline & - Falls, injuries \& fatalities & 4,12) and Exchanges during Montreal CC \\
\hline & & and OHS workshops, Nov. 24-25, 2010 \\
\hline & - Mental health disturbances & $37,38)$ \\
\hline \multirow[t]{5}{*}{ Vector-borne and zoonotic diseases } & $\begin{array}{l}\text { - Encephalitis caused by arthropods (St. Louis, La Crosse, } \\
\text { Eastern Equine) }\end{array}$ & 4) \\
\hline & - Hantavirus Pulmonary Syndrome & 4) \\
\hline & - West Nile Virus & $4,39)$ \\
\hline & - Lyme Disease & $4,40-42)$ \\
\hline & - Brucellosis & 38) \\
\hline \multicolumn{3}{|l|}{ Impacts of $\mathrm{CC}$ on natural resources } \\
\hline \multirow[t]{3}{*}{$\begin{array}{l}\text { Changes in production, harvests, } \\
\text { work methods in agriculture/breeding }\end{array}$} & $\begin{array}{l}\text { - Insecurity and consequences on physical \& mental health } \\
\text { due to a decreased employment }\end{array}$ & $6,43-45)$ \\
\hline & - Vector-borne and zoonotic diseases & $46-48)$ \\
\hline & - Variation in chemical exposure & 49) \\
\hline \multirow{4}{*}{$\begin{array}{l}\text { Changes in harvest, working meth- } \\
\text { ods in fishing }\end{array}$} & - Insecurity and consequences on mental health & 6) \\
\hline & - Diseases related to marine toxins & 50) and Exchanges during Montreal CC and \\
\hline & & OHS workshops, Nov. 24-25, 2010 \\
\hline & - Fishing under difficult conditions & $\begin{array}{l}\text { Exchanges during Montreal CC and OHS } \\
\text { workshops, Nov. } 24-25,2010\end{array}$ \\
\hline \multirow{3}{*}{$\begin{array}{l}\text { Disruption of forest ecosystem and } \\
\text { changes in distribution of toxic plants }\end{array}$} & - Allergies and lung irritation & 8) \\
\hline & - Difficult logging conditions & 6) and Exchanges during Montreal CC and \\
\hline & & OHS workshops, Nov. 24-25, 2010 \\
\hline \multicolumn{3}{|l|}{ Socio-economic context } \\
\hline \multirow[t]{4}{*}{$\begin{array}{l}\text { Deterioration of built environment } \\
\text { infrastructures }\end{array}$} & - Insecurity and consequences on mental health & $\begin{array}{l}\text { Exchanges during Montreal CC and OHS } \\
\text { workshops, Nov. } 24-25,2010\end{array}$ \\
\hline & - Environment creating new hazards & $51,52)$ \\
\hline & - Accidents related to road infrastructure damages & 51, 52) and Exchanges during Montreal CC \\
\hline & & and OHS workshops, Nov. 24-25, 2010 \\
\hline \multirow{5}{*}{$\begin{array}{l}\text { Increase in emerging «green» } \\
\text { industries }\end{array}$} & - Exposure to chemical and biological agents, and radiation & $5,8,13,53,54)$ \\
\hline & - Insecurity and consequences on mental health due to a & Exchanges during Montreal CC and OHS \\
\hline & decreased employment & workshops, Nov. 24-25. 2010 \\
\hline & - Environment creating new hazards & 53, 55-59) and Exchanges during Montreal CC \\
\hline & & and OHS workshops, Nov. 24-25, 2010 \\
\hline
\end{tabular}


Table 2. Twelve research priorities applicable to the Quebec context and identified through the modified Delphi study

\begin{tabular}{l} 
Research priorities \\
\hline Knowledge acquisition on hazards, target populations and methods of adaptation in the workplace \\
- Study past CC extreme events in order to identify type of work involved and develop mitigation strategies from this information. \\
- Evaluate new OHS hazards related to CC exposures and their potential impacts on infrastructures. \\
- Study the increased toxicity and health effects of different biological/chemical agents and materials during episodes of extreme heat, air \\
pollution, drought or intense rainfall. \\
- Assess current and future risks related to aeroallergens and zoonoses. \\
- Study thermal and hydric stress due to wearing protective equipment during extreme heat episodes. \\
- Identify categories of workers vulnerable to accidents and diseases associated with CC impacts, considering their working conditions and \\
individual characteristics. \\
\hline Surveillance of diseases, accidents and occupational hazards \\
- Define accident and disease indicators and gather information in order to enable surveillance of health effects attributable to the climate. \\
\hline Development of occupational adaptation strategies \\
- Identify and evaluate adaptation methods established in other countries. \\
- Develop training tools to prepare health care workers for the potential health effects of CC, in particular regarding heat strokes, zoonoses \\
and vector-borne diseases. \\
- Develop suitable protective clothing and other equipments that are adequate for extreme climates in order to favor their actual wearing by \\
workers. \\
- Explore CC adaptation methods using organization of work and work schedule management. \\
- Develop methods to heighten workplace (workers and employers) awareness of CC potential OHS risks, both short-term (e.g. violent storms \\
and accidents) and long-term (e.g. skin cancer and UV radiation). \\
\hline
\end{tabular}

Moreover, OHS impacts might vary within the country due to regional micro-climates or local socio-economic characteristics which will play a role in how risks and hazards will impact on population groups ${ }^{68)}$.

The second objective of this project was to determine local research priorities in order to address potential negatives impacts of CC on OHS in Quebec. The consensual research agenda obtained through the Delphi approach, which suited both stakeholders' and scientists' perceptions, showed that the most important perceived area for future work was the acquisition of knowledge; this is coherent with the fact that the topic of CC impacts on OHS has never been studied in Quebec, or in a northern industrialized country with a temperate climate. Most stakeholders of the working group reported that they had never thought about this topic in the past, but became concerned during the workshop and actively participated in the identification of the hazards, OHS effects, potentially affected industries and research priorities. Interestingly, our regional assessment brought up research topics largely similar to what Schulte and Chun ${ }^{8)}$ recommended in their conclusion. These are the improvement of epidemiologic surveillance with the development of health indicators, and also the general acquisition of knowledge on $\mathrm{CC}$ and OHS. A third topic recommended by Schulte and Chun ${ }^{8}$, namely the identification of occupational hazards related to new «green jobs», was listed among the initial research topics (increased health risks related to greener materials), but was not ranked among the top priorities after the second round of consultation.

This study presents limitations that need to be pointed out. First of all, this work has intentionally not gone very deep on CC impacts on the labor market and employment. Also, adaptation strategies were excluded from this analysis as we were not yet exploring solutions to the identified hazards ${ }^{7)}$. Secondly, this work has only targeted negative effects of CC, although some CC effects on OHS will likely be positive; for example, with adequate insect pest control, some specific agricultural production and forestry activities might even be favored, increasing revenues and job numbers in these industries. Longer mild seasons may also favor some tourist activities, such as golf, hunting and fishing ${ }^{4)}$. Thirdly, the working group selection, based on presently known CC impacts, has perhaps restricted identification of new hazards or industries during the workshop.

A delicate part of the Delphi procedure is the selection of a panel of participants that is representative of all bodies involved in the topic of interest ${ }^{69)}$; it is very likely that a different set of stakeholders and scientists would have resulted in a different research agenda. Moreover, 
the retained sets of priorities were obtained after only two consultations and it is possible that additional consultations would have resulted in a slightly different consensus. Nevertheless, the degree of unanimity among the various responses was quite satisfactory, and the excluded items essentially targeted only one or two industries, likely having a low impact in the general issue of $\mathrm{CC}$ impacts on OHS.

The research priorities were established according to scientific knowledge available at a given time and in a given economic and political context. Changes in the economic and political environments will likely bring modifications that will affect climate change mitigation ${ }^{68)}$. For instance, international pressures on greener industries will lead to labor market changes, as already experienced in the Canadian energy, postal and automotive services sectors $^{7)}$. Thus research priorities have to be revised and updated over time, following important changes in the economy, but also if there are important modifications in climate predictions or CC impacts in Quebec.

Finally, the potential health threats to workers in areas of the world with hotter climates, where people from Quebec may work or where Quebec corporations have production activities with local staff, were not reviewed, but this issue would need to be considered in future research. The potential occupational health threats from climate conditions in hotter parts of the world have been analyzed in two series of papers, published in 2009 and 2010 in the journal Global Health Action ${ }^{70,71)}$.

In conclusion, the global context of $\mathrm{CC}$ in the upcoming decades is likely to impose major changes in some industries and occupations worldwide. This work highlighted five categories of hazards that are likely to impact OHS in northern industrialized countries: heat waves /increased temperatures, air pollutants, UV radiation, extreme weather events and vector-borne/ zoonotic diseases. These hazards will affect working activities related to natural resources (i.e. bring changes in production and harvesting methods in agriculture, fishing and forestry) and may influence the socioeconomic context (deterioration of the built environment and emergence of green industries), thus indirectly modifying OHS. Our study showed that the global framework developed by Schulte and $\mathrm{Chun}^{8)}$ was relevant to address $\mathrm{CC}$ impacts on $\mathrm{OHS}$ in a temperate climate region. Bringing together regional and international experts and stakeholders proved useful to produce a consensual list of research topics. Regardless of the country considering the issue of CC impacts on OHS, it is likely that worldwide research priorities will fit into the large categories identified in our study. A concerted research effort is needed to increase our knowledge on hazards, target populations and methods of adaptation in the workplace; to ensure a proper surveillance of diseases, accidents and occupational hazards; and to develop new occupational adaptation strategies.

\section{Acknowledgements}

This work was supported by grant No. 2010-0004 from the Institute de recherche Robert-Sauvé en santé et en sécurité du travail.

\section{References}

1) Séguin J (2008) Human Health in a Changing Climate: A Canadian Assessment of Vulnerabilities and Adaptative Capacity, 546, Health Canada, Ottawa.

2) IPCC (2007) Climate Change 2007: Synthesis Report. Contribution of Working Groups I, II and III to the Fourth Assessment Report of the Intergovernmental Panel on Climate Change Core Writing Team, Pachauri, R.K and Reisinger A (Eds.), 104, IPCC, Geneva.

3) D'Amato G, Cecchi L (2008) Effects of climate change on environmental factors in respiratory allergic diseases. Clin Exp Allergy 38, 1264-74. [Medline] [CrossRef]

4) Ouranos (2010) Learning to Adapt to Climate Change. editors: DesJarlais C, Allard M, Bélanger D, Blondlot A, Bouffard A, Bourque A, Chaumont D, Gosselin P, Houle D, Larrivée C, Lease N, Pham AT, Roy R, Savard J-P, Turcotte $\mathrm{R}$, and Villeneuve C (Eds.). 128, Ouranos, Montreal. (Canada)

5) Rosenthal JP, Jessup C (2009) Global climate change and health: developing a research agenda for the NIH. Trans Am Clin Climatol Assoc 120, 129-41. [Medline]

6) UNEP/Sustainlabour (2008) Climate change, its consequences on employment and trade union action: training manual for workers and trade unions, 131, UNEP, Nairobi.

7) Lipsig-Mumme C, Calvert J, Griffin Cohen M, Hatfield R, Holmes J, Tufts S. Work in a Warming World Research Programme: What do we know? What do we need to know? http://www.workinawarmingworld.yorku.ca/projects/whatdo-we-know-what-do-we-need-to-know/. Accessed May 4, 2012.

8) Schulte PA, Chun H (2009) Climate change and occupational safety and health: establishing a preliminary framework. J Occup Environ Hyg 6, 542-54. [Medline] [CrossRef]

9) Harrington JM (1994) Research priorities in occupational medicine: a survey of United Kingdom medical opinion by the Delphi technique. Occup Environ Med 51, 289-94. [Medline] [CrossRef] 
10) Lo Vecchio F, Pizon AF, Berret C, Balls A (2007) Outcomes after environmental hyperthermia. Am J Emerg Med 25, 442-4. [Medline] [CrossRef]

11) National Oceanic and Atmospheric Administration. Heat waves- A major summer killer. http://www.nws.noaa.gov/ om/brochures/heatwave.pdf. Accessed May 1, 2012.

12) Confalonieri U, Menne B, Akhtar R, Ebi KL, Hauengue M, Kovats RS, Revich B, Woodward A (2007) Human health. Climate Change 2007: Impacts, Adaptation and Vulnerability. Contribution of Working Group II to the Fourth Assessment Report of the Intergovernmental Panel on Climate Change, Parry ML, Canziani OF, Palutikof JP, van der Linden PJ and Hanson CE (Eds.), 391-431, Cambridge University Press, Cambridge.

13) Tanaka M (2007) Heat stress standard for hot work environments in Japan. Ind Health 45, 85-90. [Medline] [CrossRef]

14) Kjellstrom T, Butler AJ, Lucas RM, Bonita R (2010) Public health impact of global heating due to climate change: potential effects on chronic non-communicable diseases. Int J Public Health 55, 97-103. [Medline] [CrossRef]

15) Gordon CJ (2005) Chapter 7. Environmental stress. In: Temperature and toxicology. An integrative comparative and environmental approach, 195-23, Taylor and Francis Group, Boca Raton.

16) Gordon CJ (2005) Chapter 4. Temperature effects on chemical toxicity. In: Temperature and toxicology. An integrative comparative and environmental approach, 107-141, Taylor and Francis Group, Boca Raton.

17) Grandjean AC, Grandjean NR (2007) Dehydration and cognitive performance. J Am Coll Nutr 26, 549S-54S. [Medline]

18) Ramsey JD (1995) Task performance in heat: a review. Ergonomics 38, 154-65. [Medline] [CrossRef]

19) Ramsey JD, Burford CL, Beshir MY, Jensen RC (1983) Effects of workplace thermal conditions on safe work behaviour. J Safety Res 14, 105-14. [CrossRef]

20) Tawatsupa B, Lim LL, Kjellstrom T, Seubman SA Sleigh A, Thai Cohort Study Team (2010) The association between overall health, psychological distress, and occupational heat stress among a large national cohort of 40,913 Thai workers. Glob Health Action 3, 10-20. [Medline]

21) Statistics Canada. Table 102-0540 - Deaths and mortality rates, by age group and sex, Canada, provinces and territories, annual, 1974 to 2008. CANSIM (database). http://www5.statcan.gc.ca/cansim/a33?RT=TABLE\&them $\mathrm{eID}=2979 \& \mathrm{spMode}=$ tables\&lang=eng. Accessed May 2, 2012.

22) Létard V, Flandre H, Lepeltier S (France- French Senate, Special Information Working Group. Information report No 195; French Senate 2003-2004 session: La France et les Français face à la canicule: les leçons d'une crise [France and the French facing the heat wave: lessons from a crisis]. http://www.senat.fr/rap/r03-195/r03-195_mono.html Accessed May 2, 2012 (in French).
23) Centers for Disease Control and Prevention. Heat-Related Deaths Among Crop Workers, United States, 1992-2006. http://www.cdc.gov/mmwr/ preview/mmwrhtml/ mm5724a1.htm. Accessed May 2, 2012.

24) Brauer M, Blair J, Vedal S (1996) Effect of ambient ozone exposure on lung function in farm workers. Am J Respir Crit Care Med 154, 981-7. [Medline]

25) Cheng MF, Tsai SS, Wu TN, Chen PS, Yang CY (2007) Air pollution and hospital admissions for pneumonia in a tropical city: Kaohsiung, Taiwan. J Toxicol Environ Health A 70, 2021-6. [Medline] [CrossRef]

26) Rage E, Siroux V, Kunzli N, Pin I, Kauffmann F (2009) Air pollution and asthma severity in adults. Occup Environ Med 66, 182-8. [Medline] [CrossRef]

27) Apte MG, Buchanan IS, Mendell MJ (2008) Outdoor ozone and building related symptoms in the base study. Indoor Air 18, 156-70. [Medline] [CrossRef]

28) Dominici F, Peng RD, Bell ML, Pham L, McDermott A, Zeger SL, Samet JM (2006) Fine particulate air pollution and hospital admission for cardiovascular and respiratory diseases. JAMA 295, 1127-34. [Medline] [CrossRef]

29) Goldberg MS, Burnett RT, Bailar JC, Tamblyn R, Ernst P, Flegel K, Brook J, Bonvalot Y, Singh R, Valois MF, Vincent $\mathrm{R}$ (2001) Identification of persons with cardiorespiratory conditions who are at risk of dying from the acute effects of ambient air particles. Environ Health Perspect 109, 487-94. [Medline]

30) Cohen AJ, Ross Anderson H, Ostro B, Pankey KD, Krzyzanowski M, Kunzli N, Gutschmidt K, Pope A, Romieu I, Samet JM, Smith K (2005) The global burden of disease due to outdoor air pollution. J Toxicol Environ Health A 68, 1301-7. [CrossRef]

31) Peden D, Reed CE (2010) Environmental and occupational allergies. J Allergy Clin Immunol 125, 150-160.

32) Lucas RM, McMichael AJ, Armstrong BK, Smith WT (2008) Estimating the global disease burden due to ultraviolet radiation exposure. Int J Epidemiol 37, 654-67. [Medline] [CrossRef]

33) Gallagher RP, Lee TK (2006) Adverse effects of ultraviolet radiation: a brief review. Prog Biophys Mol Biol 92, 119-31. [Medline] [CrossRef]

34) National Ag Safety Database. The dark side of the sun: sun exposure and agriculture. http://nasdonline.org/ document/928/d000769/the-dark-side-of-the-sun-sunexposure.html. Accessed May 2, 2012.

35) Centers for Disease Control and Prevention. Workplace Safety and Health Topics- UV radiation. http://www.cdc. gov/niosh/topics/uvradiation/. Accessed May 2, 2012.

36) Tak S, Bernard BP, Driscoll RJ, Dowell CH (2007) Floodwater exposure and the related health symptoms among firefighters in New Orleans, Louisiana. Am J Ind Med 50, 377-82. [Medline] [CrossRef]

37) Tak S, Driscoll R, Bernard B, West C (2007) Depressive symptoms among firefighters and related factors after the response to Hurricane Katrina. J Urban Health 84, 153-61. 
[Medline] [CrossRef]

38) Bennet $\mathrm{C}$, McMichael $\mathrm{T}$ (2010) Non-heat related impacts of climate change on working populations. Glob Health Action 3, 5640.

39) National Institute for Occupational Safety and Health. Recommendations for protecting outdoor workers from West Nile Virus Exposure. http://www.cdc.gov /niosh/ docs/2005-155/. Accessed May 2, 2012.

40) Ogden NH, Lindsay LR, Morshed M, Sockett PN, Artsob H (2009) The emergence of Lyme disease in Canada. CMAJ 180, 1221-4. [Medline] [CrossRef]

41) National Institute for Occupational Safety and Health. Workplace Safety and Health Topics-Tick borne disease. http://www.cdc.gov/niosh/topics/ tick-borne/. Accessed May 22012.

42) Center for Construction Research and Training. Hazard Alert-Lyme disease in Construction. http:// www.elcosh. org/en/document/1/d000001/hazard-alert\%253 A-lymedisease-in-construction.html. Accessed May 2, 2012.

43) World Health Organization. Gender, climate change and health- Draft discussion paper. http://www.who.int/ globalchange/publications /reports/final_who_gen der.pdf. Accessed August 13, 2012.

44) Chakraborty S, Luck Jo, Holladay G, Freeman A, Norton R, Garrett KA, Percy K, Hopkins A, Davis C, Karnosky DF (2008) Impacts of Global Change on Diseases of Agricultural Crops and Forest Trees. CAB Reviews: Perspectives in Agriculture, Veterinary Science, Nutrition and Natural Resources 3, No. 054.

45) Wheaton E, Koshida G, Jonhston T, Richards W, Wittrock V (2007) Agricultural Adaptation to Drought (ADA) in Canada- The case of 2001-2002. 25, Government of Canada- Climate change impacts and Adaptation programs. Saskatoon.

46) Slingenbergh JI, Gilbert M, de Balogh KI, Wint W (2004) Ecological sources of zoonotic diseases. Rev Sci Tech 23, 467-84. [Medline]

47) Gale P, Drew T, Phipps LP, David G, Wooldridge M (2009) The effect of climate change on the occurrence and prevalence of livestock diseases in Great Britain: a review. J Appl Microbiol 106, 1409-23. [Medline] [CrossRef]

48) Morgan ER, Wall R (2009) Climate change and parasitic disease: farmer mitigation? Trends Parasitol 25, 308-13. [Medline] [CrossRef]

49) Boxall ABA, Hardy A, Beulke S, Boucard T, Burgin L, Falloon PD, Haygart PM, Hutchinson T, Kovats RS, Leonardi G, Levy LS, Nichols G, Parson SA, Potts L, Stone D, Topp E, Turley DB, Walsh K, Wlleington EMH, Williams RJ (2009) Impacts of climate change on indirect human exposure to pathogens and chemicals from agriculture. Environ Health Perspect 117, 508-14. [Medline]

50) Fleming LE, Broad K, Clement A, Dewailly E, Elmi S, Knap A, Pomponi SA, Smith S, Solo Gabriele H, Walsh P (2006) Oceans and human health: Emerging public health risks in the marine environment. Mar Pollut Bull 53,
545-60. [Medline] [CrossRef]

51) Infrastructure Canada. Adaptating infrastructure to climate change in Canada's cities and communities-a literature review. http://cbtadaptation.squarespace. com/storage/ CdnInfrastructureAdaptation-LiteratureReview.pdf. Accessed June 5, 2012.

52) Baker CJ, Chapman L, Quinn A, Dobney K (2009) Climate change and the railway industry: a review. J Mech Eng Sci 224, 519-28.

53) Centers for disease control and prevention. Prevention through design; Green, safe and healthy jobs. http://www. cdc.gov/niosh/topics/ptd/greenjobs.html. Accessed May 2, 2012.

54) Li X, Zheng B, Wang Y, Wang X (2006) A survey of radon level in underground buildings in China. Environ Int 32, 600-5. [Medline] [CrossRef]

55) Occupational Health and Safety. Cultivating safety at wind farms. http://ohsonline.com/articles/2009/01/01/cultivatingwindfarms.aspx. Accessed May 2, 2012.

56) Madsen AM, Kruse P, Schneider T (2006) Characterization of microbial particle release from biomass and building material surfaces for inhalation exposure risk assessment. Ann Occup Hyg 50, 175-87. [Medline] [CrossRef]

57) Madsen AM (2006) Exposure to airborne microbial components in autumn and spring during work at Danish Biofuel plants. Ann Occup Hyg 50, 821-31. [Medline] [CrossRef]

58) Madsen AM, Schlunssen V, Olsen T, Sigsgaard T, Avci H (2009) Airborne fungal and bacterial components in pm1 dust from biofuel plants. Ann Occup Hyg 53, 749-57. [Medline] [CrossRef]

59) UNEP/ILO/IOE/ITUC (2008) Green Jobs: Towards Decent Work in a Sustainable, Low-Carbon World. 354, UNEP, Nairobi.

60) Kjellstrom $T$ (2009) Editorial: Climate change, direct heat exposure, heat and well-being in low and middle-income countries. Glob Health Action 2, 1958.

61) Jay O, Kenny GP (2010) Heat exposure in the Canadian workplace. Am J Ind Med 53, 842-53. [Medline]

62) Marszałek A, Konarska M, Bugajska J (2005) Assessment of work ability in a hot environment of workers of different ages. Int Congr 1280, 208-213.

63) Canadian Centre for Occupational Health and Safety. Humidex rating and work. http://www.ccohs.ca/oshanswers/ phys_agents/humidex.html. Accessed May 1, 2012.

64) Canadian Centre for Occupational Health and Safety. Skin cancer and sunlight. http://www.cchst.ca/oshanswers/ diseases/skin_cancer.html. Accessed May 2, 2012.

65) Park EK, Hannaford-Turner K, Lee HJ (2009) Use of personal protective equipment in agricultural workers under hot and humid conditions- Letter to editor. Ind Health 47, 200-1. [Medline] [CrossRef]

66) Bernard TE (1999) Heat stress and protective clothing: an emerging approach from the United States. Ann Occup Hyg 43, 321-7. [Medline] 
67) Walker SM, Ackland TR, Dawson B (2001) The combined effect of heat and carbon monoxide on the performance of motorsport athletes. Comp Biochem Physiol A Mol Integr Physiol 128, 709-18. [Medline] [CrossRef]

68) Adisesh A, Robinson E, Curran AD (2011) Climate change: enabling a better working Britain for the next 100 years. Occup Med (Lond) 61, 292-4. [Medline] [CrossRef]

69) Iavicoli S, Rondinone B, Marinaccio A, Fingerhut M (2006) Research priorities in occupational safety and health: a review. Ind Health 44, 169-78. [Medline] [CrossRef]

70) Kjellstrom T, Holmér I, Lemke B (2009) Workplace heat stress, health and productivity - an increasing challenge for low and middle-income countries during climate change. Glob Health Action 2, 2047. [Medline]

71) Nilsson N, Kjellstrom T (2010) Editorial: Climate change impacts on working people: how to develop prevention policies. Glob Health Action 3, 5774. 